INTERNATIONAL JOURNAL OF MULTIDISCIPLINARY RESEARCH AND ANALySis

ISSN(print): 2643-9840, ISSN(online): 2643-9875

Volume 04 Issue 03 March 2021

DOI: 10.47191/ijmra/v4-i3-09, Impact Factor: 6.072

Page No.- 275-281

\title{
Evaluation of Accounting Information System Quality of Construction Firms Listed on the Vietnamese Stock Exchange
}

\section{Duc Tai Do}

Faculty of Accounting, University of Labor and Social Affairs, Vietnam

\begin{abstract}
S: My study aims to analyze and assess accounting information system quality of construction firms listed on the Vietnamese stock exchange, to bring comprehensive insight about the accounting information system of construction firms. The evaluation was carried out by applying qualitative methodology and quantitative methodology to the research results and based on survey results of accountant staffs and IT staffs of construction firms. Overall, the study has identified and measured nine (9) attributes of accounting information system quality of construction firms that have great effects on accountants. There is not, statistically, significant difference in the level of accounting information system quality of construction firms listed on the Vietnamese stock exchange from these different job descriptions and different work experiences. Based on the research findings, there are recommendations regarding the construction firms. The findings contribute to the further development of accounting information system quality research and the construction industry.
\end{abstract}

KEYWORDS: accounting information system quality (AISQ), accounting information system (AIS), accounting, construction firms

JEL codes: M41, L86, L74

\section{INTRODUCTION}

In the organization management and the implementation of the internal control system, the role of the accounting information system (AIS) was very important (Nicolaou, 2000). The benefit of the accounting information system could be measured by its effects on improving decision-making process, accounting information quality, performance evaluation, internal controls, and economic transactions (Onaolapo \& Odetayo, 2012).

The goal of the accounting information system was to generate financial statements that were made available to both external and internal corporate users (Scott, 2001). AIS could successfully improve the accuracy of financial statements and governance reports (Salahi et al., 2010). AIS helped increase the reliability of financial statements and AIS quality improved accounting information quality (Salehi, 2011). A strict AIS helped prevent frauds and errors effectively and was an integral part of corporate internal governance (Nguyen et al., 2019).

The basic role of the accounting information systems in organizations was to create the accounting information quality (Susanto, 2013) or accounting information quality created by accounting information system quality (Laudon \& Laudon, 2013), contributing to helping administrators control economic - financial activities of enterprises, grasp challenges and opportunities to draw out directions, plans for management and operation of enterprises and was the basis for making economic decisions. In addition, for external objects interested in enterprises, when these subjects used qualified accounting information, they could define business plans, adjust policies and evaluate effectiveness of performance to deliver the desired goal (Gelinas \& Dull, 2012).

After about 60 years of establishment and development, construction firms in Vietnam had contributed about $30 \%$ to the country's GDP (Ministry of Construction, 2017), which showed the strong development of construction firms. However, according to Vietstock's statistics in April 2019, there was about 61.5\% of listed companies, in which listed construction and installation firms must adjust after-tax profit data according to audit results from financial statements; therefore, reducing the image and value of the enterprises, arousing doubts and concerns of investors about the financial situation and accounting information quality provided by the enterprises.

From the above reasons, evaluation of accounting information system quality of construction firms listed on the Vietnamese stock exchange is necessary and meaningful. 
Evaluation of Accounting Information System Quality of Construction Firms Listed on the Vietnamese Stock Exchange

\section{LITERATURE REVIEW}

\subsection{Accounting information system (AIS)}

The accounting information system was the main component of the enterprises' information system, as it was the only system that could provide the overall information of the enterprise to both internal and external users (Mihalache, 2011). Kieso (2011) said that the task of the accounting information system was collecting, processing of data and providing financial information to interested parties. The accounting information system was defined as a system of people, used to record, process data and provide information to the organization, and it included organizations implementing manual and automatic processes to support management (Inghirami, 2013). The accounting information system was a system that collected, stored and processed data to produce information for decision makers (Rommey, 2012). The accounting information system was a sub-system of the information system whose purpose was to collect, process and report information related to financial aspects of business operations (Gelinas et al. 2015). The accounting information system consisted of 6 main components, including: people, procedures and instructions, data, software, information technology infrastructure, and internal control (Fontinelle, 2017).

\subsection{Accounting information system Quality}

The effectiveness of the accounting information system was measured by the satisfaction of decision-makers about the quality of information generated by the quality of it (Nicolaou, 2000).

The accounting information quality came from the implementation of an accounting information system quality. The accounting information system quality was the integration of the quality of hardware, software, people, technical and technological networks, databases and users' satisfaction (Sacer et al., 2006). The accounting information system quality included flexibility, efficiency, accessibility and timeliness; the effectiveness of it was a measure of the success of meeting established goals or users satisfaction (Stair \& Reynolds, 2010).

Wongsim and Gao (2011) said that aspects of the accounting information quality had a positive relationship with the accounting information system application process.

The quality of the system was associated with the success and the information system quality scales which were consistent with the developed model, including: ease of use, ease of research, meeting the requirements of users, system features, flexibility, system sophistication, integration, system customization and of security of accounting information system (DeLone \& McLean, 2016). In the successful information system model, DeLone and McLean (2003) proposed that the success of the information system was determined by the quality of the information system and the quality of the output of the information system (the quality of the information generated). The success of the information system is considered through the use of a combination of six factors, which are: (i) quality of the system, (ii) information quality, (iii) quality of service, (iv) ) use of the system, (v) users' satisfaction and (vi) benefits achieved. The qualitied system will affect the use and satisfaction of users. The quality of the information system is concerned with measuring the actual system output and that is the desirable system characteristics: usability, validity, reliability, compatibility and time.

AIS quality was a system that must derive from the combination of appropriate components in the system, which must operate effectively to make decisions based on useful information provided from the system (Le \& Nguyen, 2020).

Based on findings from a number of previous studies and findings from the interviews with those experts, this research has identified accounting information system quality of construction firms listed on the Vietnamese stock exchange (AISQ) in nine (9) attributes as presented in Table 1 below.

Table 1: Attributes of accounting information system quality of construction firms listed on the Vietnamese stock exchange

\begin{tabular}{|c|c|c|}
\hline Code & Scale & Sources \\
\hline \multicolumn{3}{|c|}{ Accounting information system quality of construction firms (AISQ) } \\
\hline AISQ1 & Ease of use of the accounting information system & \multirow{9}{*}{$\begin{array}{l}\text { DeLone and McLean (2003), Sacer et } \\
\text { al. (2006), Stair and Reynolds (2010), } \\
\text { DeLone and McLean (2016) }\end{array}$} \\
\hline AISQ2 & Ease of researching the accounting information system & \\
\hline AISQ3 & The system includes the necessary features and functions & \\
\hline AISQ4 & Flexibility & \\
\hline AISQ5 & Highly reliability (the sophistication of the system) & \\
\hline AISQ6 & Ability to integrate with other systems & \\
\hline AISQ7 & The ability to customize (change) the system & \\
\hline AISQ8 & The security of the accounting information system & \\
\hline AISQ9 & Meeting the requirements of users & \\
\hline
\end{tabular}

Source: Author's synthesis 
Evaluation of Accounting Information System Quality of Construction Firms Listed on the Vietnamese Stock Exchange

\section{METHODOLOGY}

\subsection{Data collection}

The data collection tool in the study is a detailed questionnaire. The author conducted direct and indirect surveys of accountants and information technology staff in construction firms with many forms such as sending questionnaires directly or emailing from October to December in 2020. The content of the detailed questionnaire includes information about people surveyed, detailed information about the enterprises, and information on the scales related to the measurement of accounting information system quality (AISQ) including 9 observed variables (table 1). The observed variables (scales) are measured on a 5 point Likert scale from 1 "strongly disagree" to 5 "totally agree". The sample size in this study is 125 . The size of this sample was consistent with study of Hair et al. (1998) that the research sample must be at least 5 times the total number of indicators in the scales. The questionnaire of this study included nine (9) indicators, and therefore, the minimum sample size to be achieved is 5 * $9=45$ observations

\subsection{Data processing}

Then, data from these 125 questionnaires was cleaned and coded with the necessary information in the questionnaires, inputted the software.

Based on the theories and scales inherited from previous studies, the authors tested the reliability and value of the scale through descriptive statistics, Cronbach 'Alpha analysis, T-Test and Anova analysis. This study used SPSS22 software to process data.

\section{RESEARCH RESULTS}

\subsection{Descriptive statistics}

Information of data collected is shown in Table 2. It shows that among the 125 respondents, about $49.6 \%$ were male while the remaining 63 (50.4\%) were female. Of these, 60 of them (or $48 \%$ ) are 27 years old or younger, and $52 \%$ of the participants were over 27 years old. Among the respondents, accounting staffs accounted for $72.8 \%$, while the remaining $27.2 \%$ or 34 respondents were IT staffs. Of these, $51.2 \%$ of the participants have work experiences for 5 years or less, and over 5 years accounted for $48.8 \%$.

Table 2. Respondents by Gender, Age, Job Description, Work Experience

\begin{tabular}{|c|c|c|c|c|c|}
\hline & & Frequency & Percent & Valid Percent & $\begin{array}{c}\text { Cumulative } \\
\text { Percent }\end{array}$ \\
\hline \multicolumn{6}{|c|}{ Gender } \\
\hline \multirow[b]{2}{*}{ Valid } & Male & 62 & 49.6 & 49.6 & 49.6 \\
\hline & Female & 63 & 50.4 & 50.4 & 100.0 \\
\hline \multicolumn{6}{|l|}{ Age } \\
\hline \multirow{2}{*}{ Valid } & To 27 years old & 60 & 48.0 & 48.0 & 48.0 \\
\hline & Over 27 years old & 65 & 52.0 & 52.0 & 100.0 \\
\hline \multicolumn{6}{|c|}{ Job Description } \\
\hline \multirow{2}{*}{ Valid } & IT staffs & 34 & 27.2 & 27.2 & 27.2 \\
\hline & Accounting staffs & 91 & 72.8 & 72.8 & 100.0 \\
\hline \multicolumn{6}{|c|}{ Work Experience } \\
\hline \multirow[b]{2}{*}{ Valid } & To 5 years & 64 & 51.2 & 51.2 & 51.2 \\
\hline & Over 5 years & 61 & 48.8 & 48.8 & 100.0 \\
\hline \multicolumn{2}{|c|}{ Total } & 125 & 100.0 & 100.0 & \\
\hline
\end{tabular}

Source: Author compiled and SPSS software 22

Next, Table 3 indicates that the respondents agree with the dependent variables of "Evaluation of accounting information system quality of construction firms listed on the Vietnamese stock exchange" where nine attributes were quite high with an average of 3.78 compared with the highest of the Likert 5-point scale. All 9 attributes were rated at an average of 3.58 or higher. 
Evaluation of Accounting Information System Quality of Construction Firms Listed on the Vietnamese Stock Exchange

Table 3. Descriptive Analysis of Attributes of evaluation of accounting information system quality of construction firms

\begin{tabular}{|c|c|c|c|c|c|}
\hline \multicolumn{2}{|c|}{} & $\mathrm{N}$ & Minimum & Maximum & \multicolumn{5}{l|}{ Mean } & Std. Deviation \\
\hline Accounting information system quality (AISQ) & \multicolumn{5}{|l|}{} \\
\hline AISQ1 & 125 & 3 & 5 & 3.78 & .490 \\
\hline AISQ2 & 125 & 3 & 5 & 3.82 & .509 \\
\hline AISQ3 & 125 & 2 & 5 & 3.88 & .667 \\
\hline AISQ4 & 125 & 2 & 5 & 3.86 & .688 \\
\hline AISQ5 & 125 & 2 & 5 & 3.78 & .642 \\
\hline AISQ6 & 125 & 3 & 5 & 3.90 & .593 \\
\hline AISQ7 & 125 & 2 & 5 & 3.77 & .649 \\
\hline AISQ8 & 125 & 3 & 5 & 3.68 & .643 \\
\hline AISQ9 & 125 & 2 & 5 & 3.58 & .556 \\
\hline
\end{tabular}

Source: Author compiled and SPSS software 22

\subsection{Cronbach's Alpha}

Accounting information system quality of construction firms listed on the Vietnamese stock exchange has been measured by the Cronbach's Alpha. Results of testing Cronbach's alpha of attributes are presented in Table 4 below. The results also show that attributes of the dependent variables have Cronbach's Alpha coefficients that are greater than 0.6; and the correlation coefficients of all attributes are greater than 0.3 . So, all the attributes of the dependent variables are statistically significant (Hair et al, 2010; Hoang \& Chu, 2008).

Table 4. Results of Cronbach's Alpha Testing of Attributes Reliability Statistics

\begin{tabular}{|c|c|}
\hline Cronbach's Alpha & N of Items \\
\hline .852 & 9 \\
\hline
\end{tabular}

Item-Total Statistics

\begin{tabular}{|c|c|c|c|c|}
\hline & $\begin{array}{c}\text { Scale Mean if Item } \\
\text { Deleted }\end{array}$ & $\begin{array}{c}\text { Scale Variance if Item } \\
\text { Deleted }\end{array}$ & $\begin{array}{c}\text { Corrected Item-Total } \\
\text { Correlation }\end{array}$ & $\begin{array}{c}\text { Cronbach's Alpha if } \\
\text { Item Deleted }\end{array}$ \\
\hline AISQ1 & 30.28 & 12.413 & .308 & .859 \\
\hline AISQ2 & 30.23 & 11.841 & .461 & .847 \\
\hline AISQ3 & 30.18 & 10.259 & .687 & .822 \\
\hline AISQ4 & 30.19 & 10.221 & .680 & .824 \\
\hline AISQ5 & 30.27 & 10.474 & .522 & .825 \\
\hline AISQ6 & 30.16 & 11.281 & .583 & .842 \\
\hline AISQ7 & 30.29 & 10.803 & .575 & .836 \\
\hline AISQ8 & 30.38 & 10.866 & .601 & .836 \\
\hline AISQ9 & 30.47 & 11.171 & & .834 \\
\hline
\end{tabular}

\subsection{Independent $\mathrm{T}$ - test}

Comparison of the results of the evaluation of accounting information system quality of construction firms listed on the Vietnamese stock exchange between participants have work experiences for 5 years or less with those over 5 years can be seen in Table 5. According to the results shown in Table 5, Sig Levene's Test is 0.392; which is more than 0.05. The variance between the two 5 years or less and over 5 years work experiences is not different. Moreover, Sig value T-Test $=0.299>0.05$, which means that there is not, statistically, significant difference in the level of accounting information system quality of construction firms from these different work experiences (Hair et al, 2010; Hoang \& Chu, 2008). 
Evaluation of Accounting Information System Quality of Construction Firms Listed on the Vietnamese Stock Exchange

Table 5. Differences of accounting information system quality of construction firms between participants 5 years or less work experiences and over 5 years work experiences - Independent Test

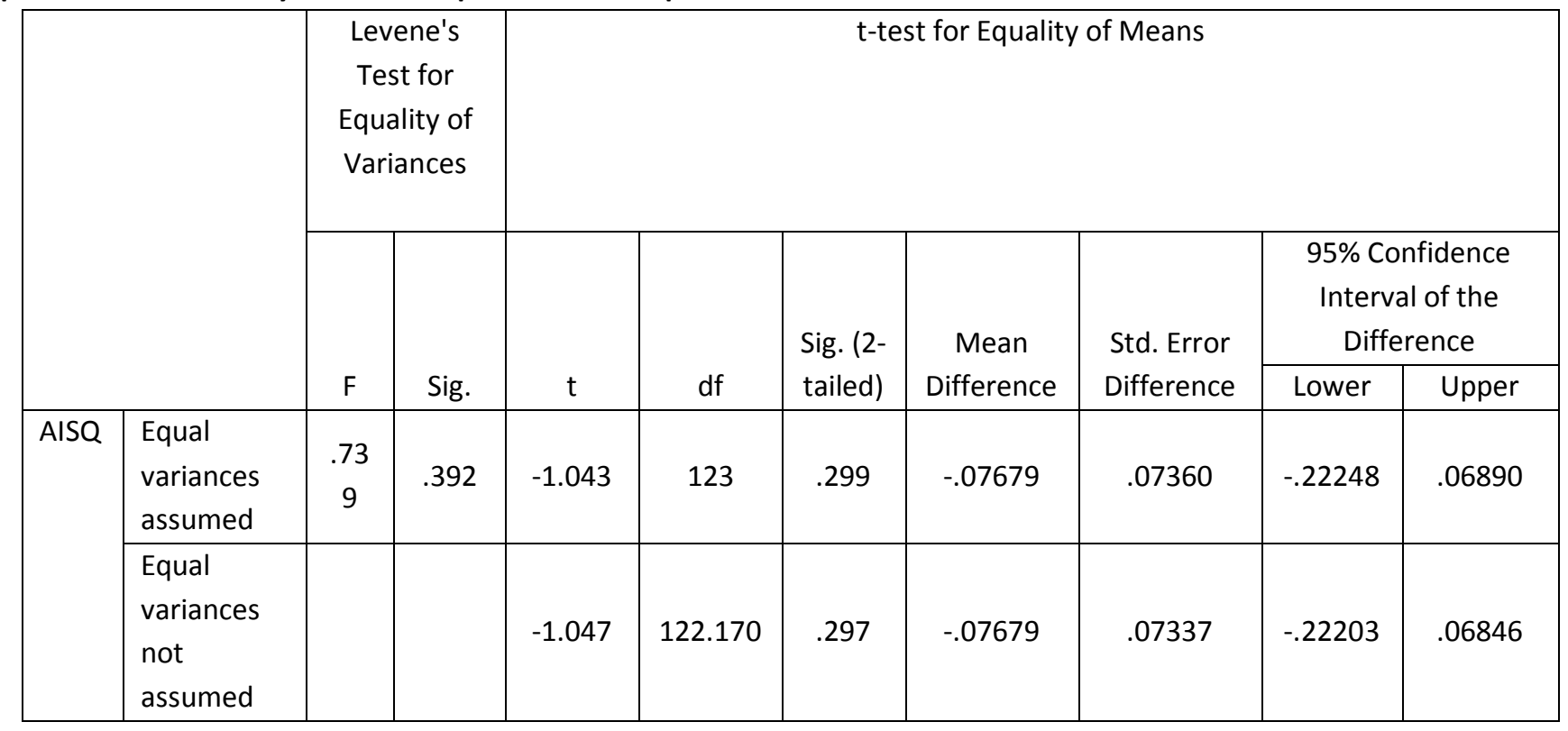

Comparison of the results of the evaluation of accounting information system quality of construction firms listed on the Vietnamese stock exchange between participants have different job description (accounting staffs with IT staffs) can be seen in Table 6. According to the results shown in Table 6, Sig Levene's Test is 0.023 ; which is less than 0.05 . The variance between the two 5 years or less and over 5 years work experiences is different. Moreover, Sig value T-Test $=0.734>0.05$, which means that there is not, statistically, significant difference in the level of accounting information system quality of construction firms from these different job description (Hair et al, 2010; Hoang \& Chu, 2008).

Table 6. Differences of accounting information system quality of construction firms between participants have different job description - Independent Test

\begin{tabular}{|c|c|c|c|c|c|c|c|c|c|c|}
\hline & \multicolumn{2}{|c|}{$\begin{array}{l}\text { Levene's Test } \\
\text { for Equality } \\
\text { of Variances }\end{array}$} & \multicolumn{7}{|c|}{ t-test for Equality of Means } \\
\hline & & \multirow[b]{2}{*}{$\mathrm{F}$} & \multirow[b]{2}{*}{ Sig. } & \multirow[b]{2}{*}{$\mathrm{t}$} & \multirow[b]{2}{*}{$d f$} & \multirow{2}{*}{$\begin{array}{l}\text { Sig. }(2- \\
\text { tailed) }\end{array}$} & \multirow{2}{*}{$\begin{array}{c}\text { Mean } \\
\text { Difference }\end{array}$} & \multirow{2}{*}{$\begin{array}{l}\text { Std. Error } \\
\text { Difference }\end{array}$} & \multicolumn{2}{|c|}{$\begin{array}{l}95 \% \text { Confidence Interval } \\
\text { of the Difference }\end{array}$} \\
\hline & & & & & & & & & Lower & Upper \\
\hline \multirow[t]{2}{*}{ AISQ } & $\begin{array}{l}\text { Equal variances } \\
\text { assumed }\end{array}$ & 5.281 & .023 & -.276 & 123 & .783 & -.02288 & .08302 & -.18720 & .14145 \\
\hline & $\begin{array}{l}\text { Equal variances } \\
\text { not assumed }\end{array}$ & & & -.341 & 96.889 & .734 & -.02288 & .06704 & -.15594 & .11019 \\
\hline
\end{tabular}

\section{DISCUSSIONS AND IMPLICATIONS}

In construction and installation firms, bidding through many criteria such as bid prices, financial capacity, etc. is one of the main forms for enterprises to perform when looking for construction works. In addition, competition in the construction industry is increasingly fierce due to the participation of many foreign enterprises and construction corporations with abundant capital, and they use modern technology and techniques, etc. into construction and installation business. Therefore, accounting information quality of construction firms must be improved more and more, ensuring trustworthiness from investors. At that time, improving accounting information systems is an urgent requirement for construction firms.

The production and construction characteristics of construction firms are usually outdoors, depending on weather factors, the construction time is often long, it takes time for the stage of acceptance, handover and settlement between investors and contractors, etc. In addition, products of construction firms are works, work items with great value, long using time. Therefore, accounting information quality about production costs needs to be accurate and timely in order to best serve users. The good quality of the accounting information system will create high-quality accounting information. 


\section{Evaluation of Accounting Information System Quality of Construction Firms Listed on the Vietnamese Stock Exchange}

Construction and installation enterprises record revenue in the form of estimating completed work volume. Therefore, the scale of revenue will change if the construction firms change the estimated rate, thereby profit will change and affect firm performance. Therefore, construction firms need to supplement and complete the accounting information system in general and the accounting information system for the revenue accounting cycle in particular.

According to experts, in the forthcoming period, the demand for investment in civil, industrial and infrastructure construction in Vietnam tends to increase significantly. Construction firms that want to survive, develop, expand production and business scale need to have financial autonomy, improve firm performance, update economic information, proactively improve the AISQ to collect and provide high-quality accounting information.

In terms of an essential relationship, AIS was also an information system and had the character of an information system. The effectiveness of information systems was related to the collection, processing, storage and security of accounting information, so that the organization could obtain qualified financial statements (Pornpandejwittaya \& Pairat, 2012).

Over the past few decades, the accounting information system has been defined by different models and approaches. Recently, AISQ has received a lot of attention because of the importance of information it brought, and more and more organizations would depend on AIS (Susanto, 2013).

The AISQ could help determine whether a project was a success or a failure, so that managers could make the right decisions and fit the project's conditions. In addition, AIS was built with the main purpose of processing accounting data from various sources into accounting information needed by different users to reduce risk when they made decisions (Sunsato, 2013). AISQ was a data collection and data processing that generated essential accounting information for users (Bagranof, 2009).

AISQ improved the quality of financial statements and promoted transaction processing for enterprises (Sajady et al., 2012).

The accounting information systems among different firms were different (Kieso et al. 2011). They were designed to suit the appropriate conditions and situations for each enterprise (Hoque, 2002).

Accounting information and reports are created by the accounting information system with reliable data, which have sufficient basis to verify the quality of provided accounting information and reports. Therefore, accountants provide honest, neutral and objective information to users. AISQ is the basis for assisting in the generation of quality information used in the decision-making process.

Information system quality was an integrated system of information systems, consisting of interrelated elements and subsystems (Susanto, 2013).

The accounting information system in listed construction firms has divided responsibilities, regulations and controlling access to accounting information for each relevant individual and department. Legitimate users can easily connect, search and access information. Information can only be deleted, edited, modified or destroyed by authorized entities. Information in general and accounting information in particular cannot be accessed or disclosed in contravention of regulations because it has been stored, transmitted safely, and ensured its accuracy.

Organizations should develop information systems to ensure that the economic events of entities were promptly and reasonably recorded for the provision of qualified information (Arens et al., 2008). The quality of systems focused on generating information which was relevant to technical qualifications. Information quality was the product of an information system corresponding to the level of users (Susanto, 2013).

Through the application of AISQ, users obtained qualified information at the right time to make decisions to produce, and to allocate resources and response times as possible leading to cost reductions and profit gains (Laudon \& Laudon, 2012). AIS were an important factor for the success of an organization by facilitating day-to-day operations and providing useful information for business management (Gelinas \& Dull, 2012).

Users' perception of the effectiveness of AIS was measured by perceptions of decision-makers' satisfaction in terms of testing the accuracy and efficiency of the information generated (Nicolaou, 2011).

\section{REFERENCES}

1) Arens, A, A., Elder, R. J., \& Mark, S. B. (2008). Auditing and Assurance Services: An Integrated Approach. 12th Edition. Pearson / Printice Hall. Education. New Jersey.

2) Bagranof, N., Mark, A., G. Simkin, G., \& Carolyn, S. N. (2009). Core concept of Accounting information systems, 7th Edition. South-Western. USA

3) DeLone, W. H., \& McLean, E. R., (2003). The DeLone and McLean Model of Information Systems Success: A Ten-Year Update. Journal of Management Information Systems, 19(4), 9-30. 
Evaluation of Accounting Information System Quality of Construction Firms Listed on the Vietnamese Stock Exchange

4) DeLone, W. H., \& McLean, E. R. (2016). Information Systems Success Measurement. Foundations and Trends ${ }^{\circledR}$ in Information Systems, 2(1), 1-116. http://dx.doi.org/10.1561/2900000005

5) Fontinelle, A. (2013). Introduction To Accounting Information Systems. Available: http://www.investopedia.com/articles/professionaleducation/11/accounting-information-systems.asp.

6) Gelinas, U., \& Dull, B. R. (2012). Accounting information systems. 9th Edition. USA: South Western Cengage Learning.

7) Gelinas, U. J., Dull, B. R., Wheeller, P., \& Hill, M. C. (2015). Accounting Information Systems. 11th Edition

8) Hair, J.F., Joseph, F.Jr., Anderson, Rolph E., Tatham, Ronald L. and Black, Wiliam C. (1998). Multivariate data analysis, 5th edition, Prentice Hall, Upper Saddle River, NJ.

9) Hair, J.F., Anderson, R.E., Babin, B.J., and Black, W.C. (2010), Multivariate data analysis: A global perspective: Pearson Upper Saddle River, ed.: NJ Publishing.

10) Hoang, T., \& Chu, N. M. N. (2008), Analysis of research data with SPSS, Hong Duc Publishing House. [Vietnamese]

11) Hoque, Z. (2002). Strategic Management Accounting. USA: Spiro Press

12) Kieso, Donald E., Weygandt, Jerry J. \& Warfield, Terry D. 2011. Intermediate Accounting. 14th Edition. John Wiley \& Sons, Inc.

13) Inghirami, I. E. (2013). Defining Accounting Information Systems Boundaries. A chapter in Accounting Information Systems for Decision Making, 2013, 185-201, from Springer

14) Laudon, K. C., \& Laudon, J. P. (2013). Management Information Systems. Managing the Digital Firm, thirteenth edition, Pearson, England.

15) Le, T. N., \& Nguyen, T. T. (2020). Determine influence the quality of the accounting information system on the accounting information quality. Journal accounting and Auditing, 3, 86-90.

16) Mihalache, A. S (2011). Risk Analysis of Accounting Information System Infrastructure (February 10, 2011). Available at SSRN: https://ssrn.com/abstract=1761465 or http://dx.doi.org/10.2139/ssrn.1761465

17) Ministry of Construction (2017). Report of the Ministry of Construction

18) Nguyen, T. B., Nguyen, A. K., \& Le, T. B. (2019). Affecting the quality of accounting information in construction enterprises in Ho Chi Minh city. Industry and trade Magazine, 17, 286-292

19) Nicolaou, A. I. (2000). A contingency model of perceived effectiveness in accounting information systems: Organizational coordination and control effects. International Journal of Accounting Information Systems 1(2):91-105. DOI: 10.1016/S1467-0895(00)00006-3.

20) Onaolapo, A. A., \& Odetayo, T. A. (2012). Effect of Accounting Information System on Organisational Effectiveness: A Case Study of Selected Construction Companies in Ibadan, Nigeria. American Journal of Business and Management, 2(1), 183189. DOI: $10.11634 / 216796061706210$

21) Pornpandejwittaya \& Pairat. (2012). Effectiveness of AIS: Effect on Performance of Thai-Listed Firm in Thailand. International Journal of Business Research. 12(3).

22) Rommey, M. B., \& Steibart, P. J. (2012). Accounting Information Systems, 12th Edition, Pearson, USA.

23) Sacer, I. M., Zager K., \& Tusek B. (2006). Accounting Information System's Quality as The Ground for Quality Business Reporting. IAIDS International Conference e-commerce, 23(2), 59-64.

24) Sajady, H., Dastgir, M., \& Nejad, H. H. (2012). Evaluation of the effectiveness of accounting information systems. International Journal of Information Science and Management (IJISM), 6, 49-59.

25) Salahi, M., Rostami, V., \& Mogadam, A. (2010). Usefulness of AccountingInformation in Emerging Economy: Empirical Evidence of Iran. International Journal of Economics and Finance, 2(2), 186-195. DOI:10.5539/ijef.v2n2p186

26) Salehi, M. (2011). A study of the barriers of implementation of accounting information system: Case of listed companies in Tehran Stock Exchange. Journal of Economics and Behavioral Studies, 2(2), 76-85.

https://doi.org/10.22610/jebs.v2i2.224

27) Scott, G. (2001). Principles of management informations Systems. McGrawHill-NewYork.

28) Stair, R. M., \& Reynolds. G. W. (2010). Principles of informations Systems, Course Technolory, $9^{\text {th }}$ Editions, Mc-Graw-Hill, New York.

29) Susanto, A. (2013). Accounting information systems development of risk control structure, Prime Edition, First mold, Lingga Jaya, Bandung.

30) Wongsim. M., \& Gao, J. (2011). Exploring Information Quality in Accounting Information Systems Adoption. Communications of the IBIMA 14(2), IBIMA publishing, Australia, 1-12.. DOI: 10.5171/2011.683574 